\title{
Duff on the Legitimacy of Punishment of Socially Deprived Offenders
}

\author{
Peter Chau
}

Published online: 13 March 2012

(C) The Author(s) 2012. This article is published with open access at Springerlink.com

\begin{abstract}
Duff offered an argument for the conclusion that just or legitimate punishment of socially deprived offenders in our unjust society is impossible. One of the claims in his argument is that our courts have the standing to blame an offender only if our polity has the right to do so since our courts are acting as the representatives of, or to use the exact phrases by Duff, "in the name of", or "on behalf of", the whole polity. In this paper I will challenge that claim. I will argue that the courts can be seen as acting, not on behalf of the whole polity, but only on behalf of a subset of its citizens, namely, the just citizens (i.e. the citizens who cannot be seen to have wronged the deprived offenders).
\end{abstract}

Keywords Punishment $\cdot$ Standing $\cdot$ Blame $\cdot$ Social justice

\section{Introduction}

Duff offered an argument for the conclusion that just or legitimate punishment of socially deprived offenders in our unjust society is impossible (1998, 2000, 2001, pp. 179-201; 2007, pp. 191-194; 2010a). His argument can be laid out in a schematic form:

P1 Legitimate punishment of an offender requires that our courts have the right or standing to blame that offender (or call that offender to account).

P2 Our courts have the standing to blame an offender only if our polity has the right to do so since our courts are acting as the representatives of, or to use the exact phrases by Duff, "in the name of", or "on behalf of", the whole polity (2001, pp. 185-188; 2007, p. 53).

\footnotetext{
P. Chau

University of Hong Kong, Pokfulam, Hong Kong

P. Chau $(\bowtie)$

University of Oxford, Oxford, UK

e-mail: siu.chau@sant.ox.ac.uk
} 
P3 Given the injustice that our polity has done to deprived offenders, our polity has lost its right to blame deprived offenders. However, since our polity has not committed injustice towards non-deprived offenders, it retains the right to blame non-deprived offenders.

C Therefore, punishment of deprived offenders is illegitimate in a way that the punishment of non-deprived offenders is not.

Duff's argument is original and distinctive and it has attracted much critical attention. ${ }^{1}$ Most critics of Duff's argument focus on attacking P3 (Matravers 2006; Holroyd 2010). ${ }^{2}$ Duff, on the other hand, defends P3 by arguing that blaming and calling to account are reciprocal matters, and since the polity has not treated deprived offenders as citizens they are entitled to refuse to account to the polity for their crimes as citizens (2010a). Tadros also provides further support for P3 by arguing that the polity is an accomplice of the crimes committed by deprived offenders, and hence its standing to blame those offenders is compromised (2009).

The issue of whether P3 is true is important and interesting. In this paper, however, I want to focus on a different point of Duff's argument. I want to attack P2, the claim that our courts have the right to blame an offender only if our polity has the right to blame that offender. I will argue that the courts can be seen as acting, not on behalf of the whole polity, but only on behalf of a subset of its citizens, namely, the just citizens (i.e. the citizens who cannot be seen to have wronged the deprived offenders). If my objection is sound, then even if the polity has lost its standing to blame the deprived offenders, it will not follow that our courts have lost their standing to blame those offenders.

The structure of the rest of this paper is as follows. In the second section, I will make two clarifications about Duff's argument. In the third section, I will attack P2. In the fourth section, I will assess six objections against my argument.

\section{Two Brief Clarifications about Duff's Argument}

Before proceeding, I want to highlight two points of Duff's argument that are relevant to my critique. First, Duff's argument is not meant to be a traditional abolitionist argument. By an abolitionist argument I mean an argument which claims that punishment of all offenders is illegitimate. Duff's argument is meant to draw a distinction between legitimacy of punishment of deprived offenders and legitimacy of punishment of non-deprived offenders (1998, p. 196; 2001, p. 195, 197; 2007, pp. 191-193). Duff's argument, in other words, is meant to be deprivation-sensitive.

Second, what does it mean to say that "our polity acted unjustly", and that "our polity has lost its right to blame some offenders"? By saying that the polity acted unjustly, certainly Duff cannot mean that everyone in the polity acted unjustly. There are righteous people who work for social justice and donate a large amount of their income to help the poor in any unjust society. I think what Duff means by saying "the polity acted unjustly" is

\footnotetext{
${ }^{1}$ One of the distinctiveness of Duff's argument is that it focuses on the legitimacy of blaming deprived offenders instead of the legitimacy of imposing hard treatments on them. For an argument for the illegitimacy of punishment of deprived offenders that focuses on the hard treatment component, see Murphy's "Marxism and Retribution" (1973).

2 They argue that even if the polity has acted unjustly in the distributive sphere, it does not follow that it loses its right to blame deprived offenders for all kinds of criminal wrongs.
} 
that the citizens, as a collective, acted unjustly. ${ }^{3}$ We should notice that by saying that a collective did something we do not imply that everyone constituting the collective did that thing: by saying that US went to war we do not imply that every US citizen went to war. Similarly, by saying that the polity has lost its right to blame an offender, I think what Duff means is that the citizens, as a whole, have lost their right to blame that offender, and this does not imply that everyone in the polity has lost his or her right to blame that offender. ${ }^{4}$

\section{P2 Attacked: An Alternative Conception of Criminal Proceedings}

Why should we believe P2, the claim that our courts have the standing to blame an offender only if our polity has the right to blame that offender? Duff seems to believe that is so because our courts have the right to blame an offender only if the persons on whom behalf the courts act have the right to blame that offender, and that our courts must be seen as acting on behalf of the whole polity in criminal proceedings.

I want to argue, to the contrary, that our courts need not be seen as acting on behalf of the whole polity in criminal proceedings. They can be seen as acting on behalf of a subset of the citizens, namely, the just citizens, in criminal proceedings. Since the just citizens, who have not committed injustice towards the deprived offenders, retain their standing to blame those offenders despite the fact that our polity is unjust, the fact that our polity has lost its standing to blame deprived offenders does not entail that our courts have lost their standing to blame them.

In fact, I would think this is a natural response. Perhaps an analogy can illustrate my point. Suppose that I promised both of my parents to do a task, say, to attend a university. Now, for some reason, my father loses his right to enforce his promise. Perhaps, for example, he waived his right to enforce my promise and thus released me from my duty to him. Suppose now my sister is sent as a representative by my parents to ask me to attend a university. If I reply to her that I no longer owe the duty to the parents as a whole, it seems that she can legitimately reply that her standing to enforce the promise is not compromised. She can say something like: yes, you may not owe a duty to our parents as a whole now, but you still owe a duty to our mother, and I am now acting on behalf of her. Analogously, why can't the courts say, in response to a challenge to their standing by deprived offenders, the following: yes, you may not owe a duty to account for your crimes to the polity as a whole now, but you still owe a duty to account to the just citizens, and I am now calling you to account on behalf of them?

\section{Six Possible Objections on Behalf of Duff}

Duff has not explicitly considered this attack of P2 so it is hard to know what his exact reply would be. Without implying that he would accept any of the following, I wish to outline six objections to my critique on behalf of him. I will argue that all of them fail.

The first objection can be called the authorisation objection. According to it, since the just citizens have not authorised the courts to blame offenders on behalf of them, the courts cannot be seen, as my position would hold, as acting on behalf of them.

\footnotetext{
3 This interpretation can find textual support in Duff's work, as Duff often talks about "the collective hand" of the polity, etc. See Duff (2001, p. 188; 2007, pp. 191-192).

4 Duff seems to agree on this point. See Duff (2001, p. 188).
} 
I have two replies to this objection. My first reply to the authorisation objection is that if authorisation is the problem, then the problem can easily be solved by asking the just citizens to authorise the courts. The standing of the courts can then be recovered over night, if just citizens do whatever is required (e.g., submitting letters) to authorize them. Duff's argument then fails to show that just punishment of deprived offenders in an unjust society is impossible, as radical restructuring of the society towards social justice in the ways that Duff envisaged is unnecessary for the courts to recover their right to blame. ${ }^{5}$

My second reply to the authorisation objection is that if lack of authorisation is a problem, the problem is a general one that applies to punishment of all offenders, whether deprived or not, and is not limited to punishment of deprived offenders. For how exactly can we say the courts are authorised to blame the non-deprived offenders but not the deprived offenders? To illustrate, suppose we insist that authorisation requires actual explicit consent. On this test, of course, the just citizens have not authorised the courts to punish the deprived offenders in most societies. But on this test it is hard to see how the courts have been authorised by the whole polity, as Duff would want to say, to punish non-deprived offenders in most societies as well. ${ }^{6}$ To put my point in another way, the lack of authorisation objection, if it has any force, seems to undermine the legitimacy of punishment of all offenders, and hence cannot be used to justify a deprivation-sensitive conclusion.

The second objection can be called the control objection. According to it, since the just citizens do not control the criminal proceedings, our courts cannot be seen as acting as the representative of them. Notice that this objection is different from the authorisation objection, since the concept of control is different from the concept of authorisation. ${ }^{7}$ I can authorise something without having control over whether it will happen or not. For example, suppose that I authorised my agent to do X. However, my agent would have done $\mathrm{X}$ whether or not I have authorised him. In this case, I have authorised $\mathrm{X}$ to be done, but I have no control over whether $\mathrm{X}$ would be done.

In reply to this objection, it is perhaps true that the polity as a whole has control over criminal proceedings in a way that the just citizens, who may be only a minority of the population, do not, at least in a broadly democratic state. But it seems to me that a representative can legitimately act for his representee as long as he is authorised by the representee, and control is not a necessary condition. The case of agent above aptly illustrates this point. Suppose that I authorised my agent to blame a wrongdoer on behalf of me and I am the only person in the world who has the right to blame the wrongdoer. Suppose, however, that my agent hated the wrongdoer so much that even if he is not authorised by me he would still blame that wrongdoer. It seems to me that my agent can legitimately say he is acting on behalf of me even though I do not have control.

The third objection can be called the law of the whole polity objection. According to this objection, the courts must, in a criminal process, speak the voice of the law; but the content of our criminal law (at least for statutes in a democratic polity) depends on the whole polity; therefore, courts must blame on behalf of the whole polity in criminal punishment. ${ }^{8}$

\footnotetext{
5 Duff discusses what kind of measures are required to restore the legitimacy of punishment of deprived offenders (2001, pp. 200-201; 2007, pp. 192-193).

${ }^{6}$ It is worthwhile to notice that Duff, in the context of discussing the legitimacy of international criminal law, recognizes that in order for a court to act for some people, what is needed is only "some normative relationship" between the court and those people and actual explicit consent is not necessary (2010b, p. 599).

7 For the idea of control over a legal process, see Duff (2001, p. 61).

8 I am grateful to Antony Duff for suggesting this objection.
} 
In order to assess this objection, we need to clarify one point. What exactly is meant by saying that we blame someone in the "voice of the law"? This phrase is metaphorical. A natural interpretation of the phrase is that we are blaming him because he violated the law; the object of blame is violation of the law. So understood, this objection can be broken down into the following points:

(a) The blame conveyed in criminal punishment is a kind of blame for violation of the law.

(b) The content of our laws depends on the polity as a whole.

(c) If our courts are blaming someone for violation of the law, then they must be blaming on behalf of the whole polity.

(d) Therefore, courts must be blaming on behalf of the whole polity in criminal punishment.

This objection, as interpreted, suffers from two problems. First, I think (c) is doubtful. The underlying assumption of (c) seems to be that only the entity on whom the content of some rules depends can blame a person for violation of those rules. But that assumption seems to be false. We can blame a football player for violating some football rules even if the content of football rules does not depend on us. So analogously why can't the courts act on behalf of the just citizens in blaming the offender for violating the criminal law, even if the content of our criminal law does not depend (only) on the just citizens? Second, and more importantly, I think (a) is false (and I believe Duff would agree with me on this point). Blame conveyed in criminal punishment is, as Duff himself has pointed out, primarily a kind of blame, not for violation of the law, but for violation of duties we are accountable towards our fellow citizens, duties which can exist independently of the law ${ }^{9}$ : when we punish a murderer, the primary condemning message we should send is not against rule-breaking. Rather, we should be blaming the offender for murdering, a kind of wrong that can be committed even if there are no legal rules.

The fourth objection can be called the diminution of standing objection. ${ }^{10}$ According to it, the just citizens' right to blame an offender is less than the whole polity's right to blame that offender. Therefore, since the courts can act for the whole polity in blaming nondeprived offenders but can only act for the just citizens in blaming deprived offenders, the courts' standing to blame deprived offenders is compromised as compared to their standing to blame non-deprived offenders.

But why should we believe that the polity's right to blame is stronger than the right held by just citizens? One suggestion would be that number matters: since the number of people constituting the whole polity must be larger than the number of just citizens, the polity's right to blame is stronger. But this suggestion will face counter-intuitive implications: does it mean, for example, that courts in China will have stronger right to blame than the courts in England, since China has a larger population? While the strength of some rights depends on numbers, it is clear that the strength of other rights, including the right to blame, does not.

Another suggestion for why the polity's right to blame is stronger than the just citizens' right to blame is that the polity's right to blame is an irreducibly collective right. On this line of thought, the right to blame held by the polity is an irreducibly collective right, entailing a duty on the part of the offender to account, not merely towards all individual

\footnotetext{
${ }^{9}$ Duff himself does not seem to dispute this point. He says that it is mistaken to see the violation of the law, per se, as the object of blame, at least for the central mala in se (1986, pp. 211-217).

${ }^{10}$ I am grateful to Massimo Renzo for suggesting this objection.
} 
citizens, but also towards the polity as an irreducible collective; it is more than the aggregate of the individual rights to blame held by all citizens constituting the polity, and thus it is more than the aggregate of the individual rights to blame held by just citizens.

To this suggestion my first reply is that it is unclear that there are really irreducibly collective rights. My second reply is that even if we can make sense of the idea of irreducibly collective rights, the particular collective right on the table is extremely obscure. For that right implies a duty to account to a collective entity, which cannot be reduced to a duty to account to individual people constituting the entity. I can understand why, after committing some wrong, I ought to account to some individual people, like victims or other citizens. I need to repair my relationship with them. But it is wholly mysterious to me why, after committing some wrong, I ought to account to some nonpersonal collective entity.

The fifth objection can be called the public resources objection. ${ }^{11}$ According to this objection, public resources can only be legitimately used for the pursuit of aims on behalf of the whole polity. If courts in criminal proceedings act on behalf of only a subset of citizens but use resources that belong to the whole polity, then they act illegitimately.

I have two replies to this objection. My first reply to the public resources objection is that even if this objection can successfully establish the claim that punishment of deprived offenders is illegitimate, we should observe that the kind of illegitimacy involved is very different from the kind of illegitimacy originally alleged in Duff's argument. According to Duff's argument, punishment of deprived offenders is illegitimate because it violates their rights. On the public resources objection, by contrast, the illegitimacy of punishing the deprived offenders lies in the violation of rights, not of the deprived offenders, but of the unjust citizens, since they are the ones who can complain that the courts are not acting on behalf of them while using their resources. My second reply to the public resources objection is that as (a) the courts do not violate the right of a person if they use his resource to do something that he has a duty to do even if the courts do not act in his name in doing so; and (b) unjust citizens have a duty to blame, it follows that the courts can legitimately use the unjust citizens' resources to fund a blaming system even if the system is not blaming in the name of the unjust citizens. I think (a) is relatively uncontroversial. I think (b) is true as well. It will be beyond the scope of this paper to defend the claim that every citizen has a duty to blame. But it is worthwhile to disarm one objection against (b). My opponents may object to (b) by saying that since unjust citizens lose their right to blame, they also lose their duty to blame. But this objection to (b) is unsound, since it does not generally follow from the fact that I lose the right to do X that I also lose the duty to do X. The fact that I lose the right to do X normally means, instead of an evaporation of the duty to do $\mathrm{X}$, that now I face a moral dilemma: I have a duty both to do $\mathrm{X}$ and not to do $\mathrm{X}$.

The final objection can be called the lynching objection. According to this objection, if the courts do not act on behalf of the whole polity in the criminal process, then the process looks, disturbingly, like lynching. ${ }^{12}$

In reply, if the courts act for the just citizens, instead of the whole polity, in punishing a deprived offender, then this process of course, trivially, shares one feature with lynching: namely, it is not a kind of punishment on behalf of the whole polity. But in order to understand whether it is therefore objectionable we need to first answer what is so problematic about lynching. I can think of several problems with lynching. First of all, lynch mobs often act angrily and thus the terms of punishment inflicted by them are often

\footnotetext{
11 I am grateful to Victor Tadros for suggesting this objection.

12 I am grateful to Antony Duff and Victor Tadros for suggesting me to think about this objection.
} 
disproportionate. Second, one who is a subject of lynching is usually not accorded with the relevant procedural protections in trial. Third, lynching disrupts the rule of law, by suggesting people to break the law and take the law in their own hands. Fourth, sometimes a person who committed a wicked act without violating the law is lynched, and as such, lynching sometimes violates the requirement of fair warning.

But none of these problems applies (at least none of them necessarily applies) to my suggestion, which requires us to understand the courts as acting on behalf of the just citizens rather than the whole polity in punishing deprived offenders. First, I have only suggested a change in understanding who the courts could act on behalf of in a criminal process. I have not advocated any change in gravity of punishment. As such, punishment on behalf of just citizens need not be disproportionate. Second, in proposing that the courts could act on behalf of the just citizens rather than the whole polity, I have not advocated any change in trial procedure, and I cannot see any such change would be entailed if the courts are acting on behalf of the just citizens rather than the whole polity. As such, I can see no reason why defendants must be offered less procedural safeguards if the courts blame them on behalf of just citizens rather than on behalf of the whole polity. As to the third and the fourth problems, the courts need not be violating the rule of law when they punish an offender on behalf of the just citizens. The questions of whether violation of a valid law is a necessary condition of criminal punishment and whether and when a valid law should be obeyed are, so far as I can see, entirely different questions from the issue of who the courts are acting on behalf of in criminal punishment.

\section{Conclusion}

Let me briefly sum up my main points in this paper. Duff argues that courts must be seen as acting on behalf of the polity as a whole in criminal proceedings, so if the polity loses its standing to blame an offender our courts would also lose their standing to blame that offender. As a result of that, given that our polity has lost its right to blame deprived offenders, our courts have also lost their right to blame deprived offenders. In reply, I argued that the courts can be seen as acting, not on behalf of the whole polity, but on behalf of a subset of it, namely, the just citizens, in criminal proceedings. Therefore, the fact that the polity has lost the standing to blame deprived offenders does not entail that our courts have also lost their standing to blame those offenders. I have examined six objections against my position (authorisation, control, law of the whole polity, diminution of standing, public resources, and lynching), and I have argued that none of them works.

Acknowledgments I am grateful to Frank Choi, Antony Duff, John Gardner, Daniel McDermott, participants of the Criminalization Conference in Stirling University (Sep 2011), and an anonymous reviewer for their helpful comments. I am grateful to the Swire Educational Trust for its financial support.

Open Access This article is distributed under the terms of the Creative Commons Attribution License which permits any use, distribution, and reproduction in any medium, provided the original author(s) and the source are credited.

\section{References}

Duff, R. A. (1986). Trials and punishments. Cambridge: Cambridge University Press.

Duff, R. A. (1998). Principle and contradiction in the criminal law. In R. A. Duff (Ed.), Philosophy and the criminal law (pp. 156-204). Cambridge: Cambridge University Press. 
Duff, R. A. (2000). Whose Law is it anyway? Inclusion, exclusion and the criminal law. Scottish Affairs, 30, $2-15$.

Duff, R. A. (2001). Punishment, communication, and community. Oxford: Oxford University Press.

Duff, R. A. (2007). Answering for crimes. Oxford: Hart Publishing.

Duff, R. A. (2010a). Blame, moral standing, and the legitimacy of criminal trial. Ratio, 23(2), 123-140.

Duff, R. A. (2010b). Authority and responsibility in international criminal law. In S. Besson \& J. Tasioulas (Eds.), The philosophy of international law (pp. 589-604). Oxford: Oxford University Press.

Holroyd, J. (2010). Punishment and justice. Social Theory and Practice, 36(1), 78-111.

Matravers, M. (2006). Who's still standing: a comment on Antony Duff's preconditions of criminal liability. Journal of Moral Philosophy, 3(3), 320-330.

Murphy, J. (1973). Marxism and retribution. Philosophy \& Public Affairs, 2(3), 217-243.

Tadros, V. (2009). Poverty and criminal responsibility. The Journal of Value Inquiry, 43(3), 391-413. 